Brit. F. vener. Dis. (1970) 46, 138

\title{
Value of re-interviewing in contact tracing
}

\author{
T. Z. CAPIŃSKI AND J. URBAŃCZYK \\ Krakow, Poland
}

IN Poland, a person in whom venereal disease has been diagnosed is obliged by law to indicate the contacts who could have been the source of infection and all those to whom the disease could have been transmitted.

So far, traditionally, and because of the lack of professional contact investigators or well-trained para-medical personnel, it is usually the doctor who interviews his patient.

For some time the number of contacts named by VD patients interviewed at the dermatological clinics in Krakow has been declining. Since successful interviewing is a most important factor in efficient contact tracing, an attempt was made to prove the value of re-interviewing when performed by a trained investigator, working at a different place and in pleasant surroundings.

Of the patients in whom early symptomatic syphilis was diagnosed in Krakow in 1968, 160 who had failed to name their contacts when first interviewed by the physician were re-interviewed at the Provincial Dermatological Clinic in Krakow by an experienced interviewer qualified in psychology. The best possible conditions for success, such as an interview room providing adequate comfort and privacy, sufficient time, etc., were arranged so as to gain the patients' confidence and enhance their cooperation in furnishing the necessary information.

Locating contacts, a second essential element of the procedure, was the work of a separate team from the Staff of the Provincial Dermatological Clinic, and was carried out partly by post and partly by field workers.

\section{Material}

Table I shows the distribution of the patients interviewed by age, sex, and marital status. There were three times as many males (122) as females (38). The majority (118) belonged to the age group 20 to 40 years. There were seventeen teenagers, and eleven patients over 50 , with four over 60 . Nearly two-thirds (101) were single, and the remaining 59 were married.
TABLE I Age, sex, and marital status of 160 faticnt re-interviewed

\begin{tabular}{|c|c|c|c|c|c|}
\hline \multirow{2}{*}{$\begin{array}{l}\text { Age group } \\
\text { (yrs) }\end{array}$} & \multirow{2}{*}{ Sex } & \multicolumn{3}{|c|}{ Marital status } & \multirow{2}{*}{$\begin{array}{l}\text { Total in } \\
\text { Age group }\end{array}$} \\
\hline & & Single & Married & Total & \\
\hline $15-19$ & $\begin{array}{l}\mathrm{M} \\
\mathrm{F}\end{array}$ & $\begin{array}{l}9 \\
7\end{array}$ & $\begin{array}{l}0 \\
1\end{array}$ & $\begin{array}{l}9 \\
8\end{array}$ & 17 \\
\hline $20-30$ & $\begin{array}{l}\mathrm{M} \\
\mathrm{F}\end{array}$ & $\begin{array}{l}40 \\
13\end{array}$ & $\begin{array}{r}19 \\
6\end{array}$ & $\begin{array}{l}59 \\
19\end{array}$ & 78 \\
\hline $31-40$ & $\begin{array}{l}M \\
\text { F }\end{array}$ & $\begin{array}{r}15 \\
6\end{array}$ & $\begin{array}{r}17 \\
2\end{array}$ & $\begin{array}{r}32 \\
8\end{array}$ & 40 \\
\hline $41-50$ & $\begin{array}{l}\text { M } \\
\text { F }\end{array}$ & $\begin{array}{l}6 \\
2\end{array}$ & $\begin{array}{l}6 \\
0\end{array}$ & $\begin{array}{r}12 \\
2\end{array}$ & 14 \\
\hline Over 50 & $\begin{array}{l}M \\
\text { F }\end{array}$ & $\begin{array}{l}2 \\
1\end{array}$ & $\begin{array}{l}8 \\
0\end{array}$ & $\begin{array}{r}10 \\
1\end{array}$ & 11 \\
\hline $\begin{array}{l}\text { Total } \\
\text { patients }\end{array}$ & $\begin{array}{l}M \\
F\end{array}$ & $\begin{array}{l}72 \\
29\end{array}$ & $\begin{array}{r}50 \\
9\end{array}$ & $\begin{array}{r}122 \\
38\end{array}$ & 160 \\
\hline & Total & 101 & 59 & 160 & \\
\hline
\end{tabular}

There are too few cases for any statistically significant conclusions to be drawn relating to the socio-economic and psychological factors influencing the response of those re-interviewed, but the patients were divided according to school-years completed and occupation, into three classes (Table II).

TABLE II Education and occupation of 160 patients re-interviewed

\begin{tabular}{|c|c|c|c|}
\hline \multirow{2}{*}{$\begin{array}{l}\text { School years } \\
\text { completed }\end{array}$} & \multirow{2}{*}{ Occupation } & \multicolumn{2}{|c|}{ Patients } \\
\hline & & No. & Per cent. \\
\hline 7 or less & $\begin{array}{l}\text { Unskilled workers } \\
\text { Labourers }\end{array}$ & 76 & 48 \\
\hline 8 to 12 & $\begin{array}{l}\text { Skilled workers } \\
\text { Craftsmen } \\
\text { Drivers } \\
\text { Catering industry }\end{array}$ & 74 & 46 \\
\hline Over 12 & $\begin{array}{l}\text { Clerical and professional } \\
\text { workers }\end{array}$ & 10 & 6 \\
\hline Total & & 160 & 100 \\
\hline
\end{tabular}




\section{Findings}

Of the 160 patients re-interviewed, 111 named a total of 208 contacts.

Table III shows the response of those re-interviewed, with their distribution by age, sex and marital status, and the number of the contacts named in each group.

Better cooperation was achieved in re-interviewing the female subjects. Of the 38 females, only seven (all belonging to the age group 20 to 30 years) failed to indicate their contacts, and the remaining 31 (81 per cent.) named 83 contacts. Of 122 males, 42 did not cooperate, and eighty (66 per cent.) named 125 contacts.

As regards the relationship of marital status to cooperation with the interviewer, Table III indicates that the unmarried (both males and females) are more cooperative; 70 per cent. of unmarried men and 89 per cent. of unmarried women named their contacts, compared with 59 and 67 per cent. of married men and women respectively.

The result of the investigation of the 208 contacts named by these patients is presented in Table IV. Nineteen could not be located and 189 (91 per cent.) came for examination. Five of these were not examined; three because they had already received prophylactic treatment, and two because they refused to be examined. Syphilis was diagnosed in 88 (49 per cent.) of the 184 examined, 72 (35 per cent.) were found not to be infected, and 24 (16 per cent.) are still under medical observation for different reasons.

\section{Conclusions}

Our main purpose has been to demonstrate the epidemiological importance of the procedure and to emphasize the value of special qualities in an interviewer, such as a knowledge of the psychological principles of interviewing, and also of a pleasant and appropriate physical setting.

Our study is not yet completed, but we may draw some preliminary conclusions, especially those pertaining to the attitudes of patients with venereal disease towards sexual activity.

In the course of interviewing and re-interviewing the 160 patients and their 189 contacts, it was frequently found that one could not elicit sufficient information because the patients (mostly men), although willing to cooperate with the interviewer,

TABLE II N Naming of contacts by 160 patients re-interviewed, by marital status and sex

\begin{tabular}{|c|c|c|c|c|c|c|c|}
\hline Patients' marital status & Patients' sex & \multicolumn{2}{|c|}{ Patients naming contacts } & \multicolumn{2}{|c|}{ Patients not naming contacts } & \multicolumn{2}{|c|}{ Total patients } \\
\hline \multirow[t]{2}{*}{ Single } & $\begin{array}{l}\mathbf{M} \\
\mathrm{F}\end{array}$ & $\begin{array}{l}50 \\
25\end{array}$ & $\begin{array}{l}70 \\
89\end{array}$ & $\begin{array}{r}22 \\
4\end{array}$ & $\begin{array}{l}30 \\
11\end{array}$ & $\begin{array}{l}72 \\
29\end{array}$ & $\begin{array}{l}100 \\
100\end{array}$ \\
\hline & Total & 75 & & 26 & & 101 & \\
\hline \multirow[t]{2}{*}{ Married } & $\begin{array}{l}\mathrm{M} \\
\mathrm{F}\end{array}$ & $\begin{array}{r}30 \\
6\end{array}$ & $\begin{array}{l}59 \\
67\end{array}$ & $\begin{array}{r}20 \\
3\end{array}$ & $\begin{array}{l}41 \\
33\end{array}$ & $\begin{array}{r}50 \\
9\end{array}$ & $\begin{array}{l}100 \\
100\end{array}$ \\
\hline & Total & 36 & & 23 & & 59 & \\
\hline \multirow[t]{2}{*}{ Total } & $\begin{array}{l}\mathbf{M} \\
\mathbf{F}\end{array}$ & $\begin{array}{l}80 \\
31\end{array}$ & $\begin{array}{l}66 \\
81\end{array}$ & $\begin{array}{r}42 \\
7\end{array}$ & $\begin{array}{l}34 \\
19\end{array}$ & $\begin{array}{r}122 \\
38\end{array}$ & $\begin{array}{l}100 \\
100\end{array}$ \\
\hline & Total & 111 & & 49 & & 160 & \\
\hline
\end{tabular}

TABLE IV Findings in 208 named contacts

\begin{tabular}{|c|c|}
\hline Contacts & \\
\hline $\begin{array}{l}\text { Not located } \\
\text { Located }\end{array}$ & \\
\hline Total & \\
\hline Findings in those located & $\begin{array}{l}\text { Syphilis } \\
\text { No infection } \\
\text { Under observation }\end{array}$ \\
\hline & Total \\
\hline
\end{tabular}

\begin{tabular}{l} 
No. \\
\hline 19 \\
189 \\
\hline 208 \\
\hline 88 \\
72 \\
\hline 184 \\
\hline 5
\end{tabular}

\begin{tabular}{|c|c|}
\hline \multicolumn{2}{|l|}{ Percentage } \\
\hline Of those named & Of those examined \\
\hline $\begin{array}{r}9 \\
91\end{array}$ & \\
\hline \multirow[t]{3}{*}{100} & \\
\hline & $\begin{array}{l}49 \\
35 \\
16\end{array}$ \\
\hline & 100 \\
\hline
\end{tabular}


declared that the infection arose from a casual encounter, and that they knew nothing of the partner, sometimes not even her first name.

This pattern of casual intercourse and the multitude of named contacts (some girls aged 15 to 19 years having up to six) exemplify the marked trend towards promiscuity, especially amongst young people.

\section{Summary}

Interviewing as a preliminary to contact tracing is traditionally conducted by the physician in charge of the case. With a decline in the numbers of persons named as contacts, 160 patients with early syphilis who had failed to provide information to the doctor were re-interviewed by a skilled interviewer trained in psychology and working in pleasant surroundings without haste. This re-interviewing led to the naming of 208 contacts, 189 of whom were brought for examination, and as a result 88 cases of syphilis were detected. Reasons for patients giving inadequate information were usually the casual nature of the sexual transaction and, in the case of young girls, the multiplicity of partners.

\section{Valeur d'un deuxième entretien dans la recherche des contacts}

\section{SOMMAIRE}

Dans la recherche des contacts, l'entretien avec le malade est un premier temps qui est traditionnellement mené par le médecin qui soigne le cas considéré. Devant la faiblesse du nombre de personnes qu'ils commaient comme contacts, 160 malades atteints de syphilis récente, qui n'avaient pas fourni des informations valables au médecin, furent de nouveau interrogés par une personne spécialisée qualifiée en psychologie et travaillant sans hâte, dans une ambiance plaisante. Ce nouvel interrogatoire a fait citer 208 contacts: 189 de ceux-ci purent être examinés avec, comme résultat, la découverte de 88 cas de syphilis. Les raisons pour lesquelles les malades donnaient des renseignements sans valeur était générelement le caractère fortuit de la rencontre sexuelle et, dans le cas des filles jeunes, le grand nombre des partenaires. 